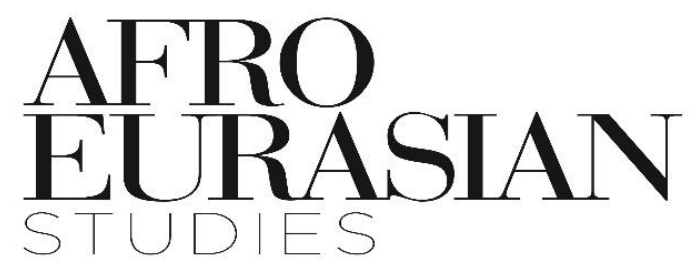

[AFES], 2019, 8 (1): 81-105

\title{
A Method Of Baiting In Internet Journalism; Fear And Threat
}

\section{Journalism}

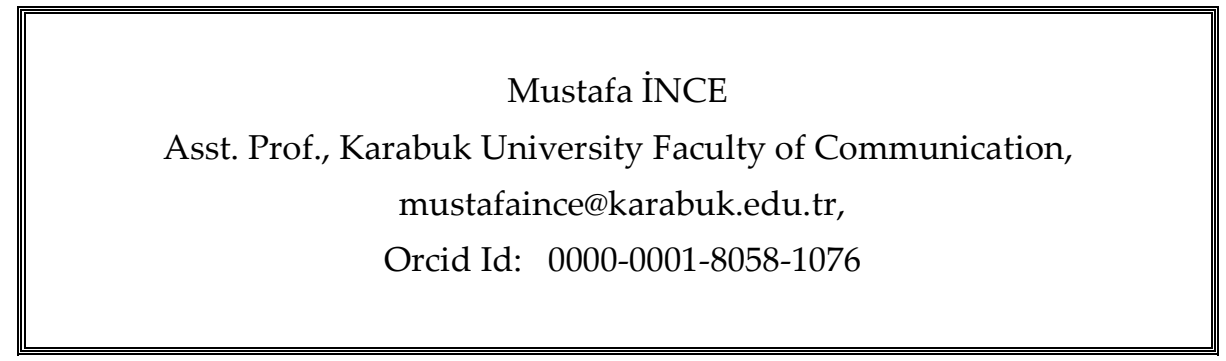

Article Information

Article Types : Research Article

Received : 23.02.2019

Accepted : 28.03.2019

Published : 28.03.2019

Pub Date Season: March 2019

Cite as: INCE, M . (2019). A Method Of Baiting In Internet Journalism; Fear And Threat Journalism. Afro Eurasian Studies, 8 (1), 81-105. Retrieved from http://dergipark.gov.tr/afes/issue/44214/532725

Plagiarism: This article has been reviewed by at least two referees and scanned via a plagiarism software.

Copyright (C) Published by MUSIAD- Ataköy 7-8-9-10 Mah. Cobancesme E5 Yanyol Cad. No:4 Bakirkoy, 34158 Istanbul / Turkey Tel +90 (212) 3953302 Fax +90 (212) 3950001 aestudies@musiad.org.tr 


\title{
A Method Of Baiting In Internet Journalism; Fear And Threat Journalism
}

\begin{abstract}
With the forced migration of traditional media to the internet environment, rating competition in televisions and circulation competition in newspapers have become the competition of being the most-clicked on the internet. In fact, this competition was seen as a struggle to survive for news sites. However, this approach worked up producing/making news with the "no matter how, as long as it is clicked" logic in internet journalism. Especially headlines were started to be created in a way which threaten, frighten and cause concern in the reader, beyond arousing curiosity. Unfortunately, this understanding meant ignoring the journalism principles and ethical orders as well as deceiving the readers. In these kind of news reports which are produced with the concern of being widely clicked and read, readers are literally forced to read those news reports since an expectation is created for them by using titles that are more assertive than it already is, which generally address to the feelings of the reader and discuss subjects that are controversial in terms of newsworthiness. In the news, frightening, worrisome, disconcerting and over-thrilling language and wording are used as well as misleading information and noncompliance between the title and the content. The news reports that are produced with this understanding deceive the readers and discredit internet journalism and internet news.

The aim of this study is to put forward the creation of a new journalism understanding which frightens, almost threatens and causes worry in the reader (compels them to read) in internet journalism. Within the scope of the research, 5 most followed internet sites in Turkey, according to the web traffic measurements of Alexa (Top Sites in Turkey) for December 2018, were monitored for 2 months. The compliance between the titles and news reports in these news sites were analyzed along with the language and wording, by examining certain news reports that are created and published in a way which threatens, frightens, causes anxiety or worry in the reader. The literature related to the subject was utilized as well.
\end{abstract}

Keywords: internet journalism, baiting, fear journalism, threat journalism 


\section{Introduction}

The innovations that internet journalism provide to the mass media are undoubtedly revolutionary. Media have probably reached its final point in terms of speed which is one of the most important elements of mass media in particular. Incidents that take place almost everywhere in the world can be transmitted to other people and sometimes to the masses in an instant by individuals in many media platforms, notably in social media. This kind of individual annunciation and breaking the news do not bear an institutional qualification and these are performed actively.

However, there are certain internet news sites that people follow regularly in order to receive news and information on a daily basis or even instantaneously. These news sites usually present news about routine progresses to their readers/followers. However, almost all of the news sites perform this. For this reason, certain news sites try to practice several new and different methods while presenting news in order to be different, to keep their current readers, to acquire new readers and thus, to reach more click rates. In this way, they could present routine news as if they were different (so to say) from other news sites and catch the opportunity to be followed more. Actually, the basis of these initiatives is to be visited more and, of course, to be clicked more. Because in today's conditions the sole criterion and proof of being "good" or "successful" of news sites are these purposes.

Normally, in journalism, subjects should be chosen in accordance with the subjects which have the most public interest and concern the majority of the people while determining the news that would be published. Yet, in internet journalism, the basic approach is to choose subjects which are ostensibly interesting and catchy, notably as frightening, worrisome, concerning, raising curiosity and even threatening. Furthermore, most of these subjects are artificially created subjects. Internet journalism, in fact, makes up news reports which fit purpose instead of reporting news. The news reports which are produced with this understanding pursue a whole different goal apart from providing information. "Click-oriented news presentation which presents news titles and visuals that accompany them and created in order to increase the click rate, is a content-managed stylistic news practice which seeks the answer for the question, how to get maximum number of clicks with the existing material 
instead of the question, how the news could be transmitted to the reader in the simplest and most correct way." (Özyal, 2016: 278). This understanding causes news reports to be presented as products which are wrapped as commercial commodities or as tempting.

Internet journalism has difficulty in carrying on for reasons such as cannot evidencing its maturity as a genuine news reports field, lack of regular income, not being institutionalized and not possessing a precise legal ground. This situation causes ignoring many journalism rules, notably ethical principles, under the name of different presentations in internet journalism. These kind of news reports which are tried to be produced with the purpose of deriving a profit directly or indirectly, become deceiving, threatening, frightening, worrying and causing anxiety instead of raising curiosity in the readers. This situation causes the creation of fear journalism.

Internet journalism which struggles to survive in today's conditions has ignored many social and professional principles and values and has adopted a way of deriving profit over the certain (sociological-psychological) tendencies of people for the sake of being widely read/clicked. One of these tendencies is fear. In fact, fear or being scared is a situation human beings are inclined to by nature. Human beings react to negative situations faster due to their creation. This situation is a natural reflex that develops automatically in order to survive. In other words, human beings are prone to perceive and to react towards threat. In this context, "Fear is a mental reaction and the natural universal situation of affection that living beings demonstrate towards the things they perceive, see or think, imagine or the dangerous and threatful situation, person, object, incident and phenomenon they design." Fear is regarded as the focalizing, accumulation and concentration of anxiety towards a situation, person, object, incident or phenomenon." (Köknel, 2004, s.16). When evaluated in this respect, it can be stated that humans tend to eliminate incident or incidents that threaten their current situation or their comfort. Using titles and statements which would mean 'you will lose if you don't read this', 'you will miss lots of things if you don't click this', 'you will regret if you don't look at this', 'it would be a mistake if you don't learn this' create a sense of anxiety in the reader instead of curiosity. Therefore, the reaction and the interest that would stimulate the feeling and emotion towards these news can be higher. 
Focusing on fear culture by the media, including cinema industry, verifies this situation. "Horror becomes more and more emerging trend within popular culture. The horror is accepted as an industry all around the world, especially in the USA. The horror industry - as it's called in USA - is an essential part of communication networks and magazine industry. As the provider and the controller of the communication industry as a means of control, hyperpowers create horror aiming the big cities. For the city-dwellers, who wants to read and watch more materials, the horror gets transformed into a provided entertainment industry and a target audience gets created, who continuously demand horror. When it's analyzed down to its sources, some kind of a social model created by language reveals itself. The imagery that is exaggerated to present the current issues and attract attention creates a hypnotic effect by positioning everything else as "viewer", "observer" or "voyeur" (Torun, 2018:63). Therefore, people are forced to show interest in the presentations for the sake of "not suffering damage", "not regretting", "not missing the opportunity", "not to fall behind" etc.

\section{The problems that emerge along with internet journalism}

A great deal of problems, violation of ethical principles and values in traditional media have also moved to the internet. As a matter of fact, certain innovations and technical opportunities that are provided by the system have caused these problems to increase.

Either in conventional publishing or in new media platforms, mass media which are expected to inform the public by looking out for the public interest, unfortunately violate the basic principles of journalism due to certain reasons (political, economical, ideological etc.). The solution of these problems and violations in a field where legal restriction is not suitable and possible is quite difficult to find and seems possible only with vocational supervision. In this context, the protection of basic values stated in The Declaration of Right and Liability of Turkish Journalists is extremely important. The practices apart from and contrary to these basic values are, at the same time, unethical practices in media. These values are; 'Acquiring the trust of the society', 'Not being an instrument to conflict of interest', Not obtaining free opportunities', 'Being 
moderate in relationships with the news sources, not mixing up with a relationship based on self-interest and emotions', 'Absence of mistakes that are performed as a result of carelessness in the news (reasons that cause mistakes are; timelessness, working fast, publishing the news of a different news source without controlling it, negligence, being unprofessional)', 'Not reporting made up or fake news' and 'Not interfering with private life'. At this point interfering with the privacy and the exploitation of private life with the justification of the right to know the truth of public is an important ethical issue which is frequently encountered in the media. The essential point here is to look out for the absolute public interest. 'The relationship of broadcasting corporations with business relations and profit resources', Impartial and objective journalism', 'Not oppressing journalists', 'Not making news on demand', 'Not producing advertising-oriented news', 'Not accepting free opportunities and gifts by which journalists acquire due to their profession', 'Consulting to honest ways while acquiring news by the journalist', Not writing the news in a way which would cause the news to be misunderstood; not making deductions, additions and/or making news in which title-spot-photographs are in compliance with', 'Not crooking the incidents for the sake of producing exciting news', 'Not publishing images and articles that constitute a contradiction to the public morality', 'Not plagiarizing other journalists' news, article and photographs', 'Defend the interests of the majority of society, opposing exploitation, looking out for the public interest in the news', 'Not exploiting religious emotions, not being racist, not publishing news and articles that would humiliate other races and/or nations', 'Not taking credit for another person's news', 'Avoiding slander, insult and malignity', 'Respect to the right of correction and reply', 'Respect to professional secrets'... Media organizations or journalists violet these ethical rules and principles by various ways notably because of commercial concerns and monopolization. (Gürcan, 2005: 42-43).

Today's internet journalism has a reverse situation in the protection of these basic values. Since internet journalism hasn't developed yet in terms of the aforementioned reasons, plenty of principles and values are violated. It is possible to state some of them as: 'Lack of editor control', in other words, not performing quality control for the news and articles, 'Publishing the content 
prematurely', the lack of time and place restriction, which is one of the opportunities provided by the internet (opportunity to report news from everywhere), and publishing the news before the information about the news reports are certain or reviewed in order to report the news quickly and this can be evaluated as an ethical problem in terms of reporting accurately. 'Deceiving title', using an exaggerated, striking and even fake title which is not directly related to the news in order to make the news to be read more. 'Gallery news', reporting the news as sentence by sentence under each photograph in order to increase the number of clicks and to keep the reader in the news/site longer. This situation causes the failure of news integrity as well as wasting the time of the reader. 'Hypertext', presenting excessively redundant and detailed information about the subject since the space is not an issue in internet journalism. This situation causes the subject to be incomprehensible, beyond wasting the time of the reader. Whereas one of the duties of journalism is to summarize the news and to make it simple and comprehensible. 'Corruption of the language (spelling mistakes)', the way of wording may cause a corruption in the language which originates from making the news to be more interesting and using the language carelessly. 'News on demand (targets a person, an institution or an establishment)' making news reports that serve a purpose apart from public interest due to the benefits of the publisher or in accordance with the demands of another person. Similarly, reporting news that are intended to publicize a commodity or a service for money. 'News plagiarism', publishing the news which was published in another site by changing some of the sentences so that it won't be a matter of lawsuit, is an important ethical problem. 'The difference of advertisement and news (secret advertisement)', presenting the advertisement to the reader in the form of video or picture unpredictably in the news site, in news link or within the news. 'Hate speech (usage of slangswears)', presenting irresponsible behaviors in the news or in another contents, thinking that the internet is a free or an uncontrolled field. 'Not indicating the sources' is an ethical issue in internet journalism either the source has been acquired from the agencies or from another place. Internet journalists present the news that they haven't endeavored as if it is their own news. 'Photomontage', manipulating the materials or the images of the news in order to make purposeful news or to make the news suitable for a purpose. 'Being 
exposed to advertisement obligatorily', advertisements are imposed to readers who click to a link in order to read the news on internet news sites either as images or videos. Advertisements are imposed upon the readers who want to read the news. This approach of which the reader does not have the right to choose is quite disruptive. 'Invasion of privacy (the exploitation of private life)' is being insensitive towards right of privacy due to reasons such as the difficulty of censoring the internet, the possibility of setting up another news site when the other one is closed and insufficient punishment for the committed actions. 'Pretending to be a journalist by people who are not journalists', journalism is an occupation which has rules, principles and special practices in itself and has tremendous responsibility towards the society. Therefore, attempting to be a journalist by buying a domain name on the internet by the people who didn't receive a certain education causes important ethical problems in internet journalism.

This and similar practices decrease the confidence in internet news, cause certain social sufferings and causes a worrisome situation in terms of the future of internet journalism. It would be beneficial to evaluate the reflection of these aforementioned ethical issues in terms of readers and society in internet journalism (Arasl1, 2011:48). Internet journalism which is rapidly changing towards an unlimited, irresponsible and unprincipled publishing, presents a new way of journalism through the fears of people. In this kind of news; the news reports are fictionalized by twisting the incidents, using exaggerated titles and changing the images and they are presented to the reader by changing it into a fit-for-purpose 'commodity'.

\section{The Research}

In this research, it was revealed that internet news sites which adopt different ways and methods in order to prove themselves, to acquire more click rates and thus increase their profitability by taking more advertisements, embraced a new journalism understanding which frightens and threats the reader and causes worry (compels them to read), with sample incidents and numeric data. 


\subsection{The Aim and the Importance of the Research}

The 'new journalism' understanding which emerged with the movement of traditional journalism to the internet, corrupted the journalism with various practices and made it different from its purpose. Thus, both the content, essence, purpose of the journalism and the confidence of the reader to the news reports are damaged. This 'new' kind of news reports which are created for various interests, have become distant from the 'informing the society' function. It is concerning for internet journalism since these 'fake' news reports which prevent the people to acquire accurate, easy and fast news, are inclined to become more and more popular. The aim of this study is to reveal the creation of a new journalism understanding which threatens and frightens the reader and causes worry in the reader (compels them to read).

\subsection{The Method of the Research}

Within the scope of the research, 5 most followed internet sites in Turkey, according to the web traffic measurements of Alexa (Top Sites in Turkey) for December 2018, were monitored (by excluding the weekends and public holidays) for 2 months. The language and the tone in the news along with the compliance/noncompliance between the title and the news reports in these news sites were analyzed with sample news by examining certain news reports that were published in a style which threatens, frightens the reader and causes anxiety and concern in the reader. News examinations in internet news sites involve news headlines. Samples about the subject were limited to 5 (five) pieces.

\subsection{The Most Followed News Sites}

In the determination of the most followed news sites, the number of visitors to the news sites was taken as a basis. In this context, the number of visitors to the news sites showed differences on a daily basis. According to the data of Alexa on the date of December 18, 2018, when the research has commenced, the most followed news site in Turkey was www.ensonhaber.com. The following sites were www.hurriyet.com.tr, www.milliyet.com.tr, www.yenisafak.com and www.mynet.com, respectively. 
How popular is ensonhaber.com?

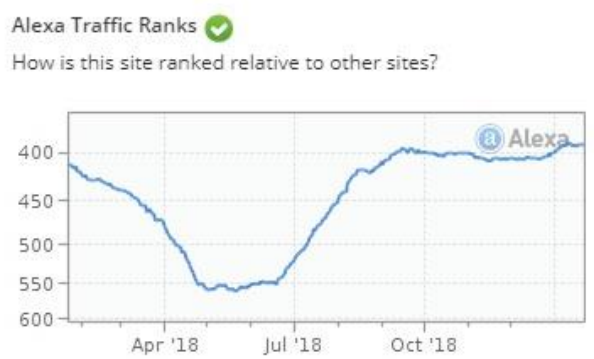

Global Rank 3

Image 1: The general and country ranking of ensonhaber.com according to the data of Alexa.

As it can be seen in Image 1, www.ensonhaber.com ranked $392^{\text {nd }}$ in the world and $5^{\text {th }}$ in Turkey in the most visited sites ranking. As it can be understood from the graphic, the number of visitors decreased from the beginning of 2018 until the midyear, but it continuously increased from July, 2018 to the end of the year.

How popular is hurriyet.com.tr?

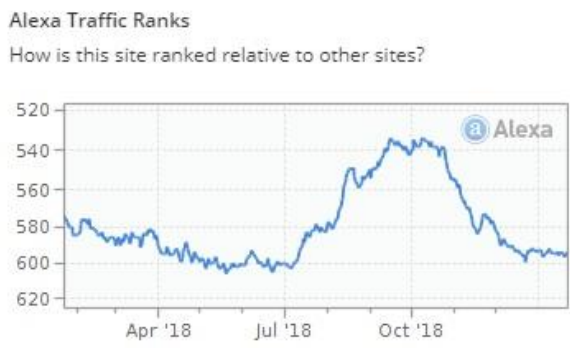

Global Rank (3)

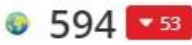

Rank in Turkey 9

10

Image 2: The general and country ranking of hurriyet.com.tr according to the data of Alexa.

As it can be seen in Image 2, www.hurriyet.com.tr ranked $594^{\text {th }}$ in the world and $10^{\text {th }}$ in Turkey in the most visited sites ranking. As it can be understood 
from the graphic, the site experienced a decrease in terms of the number of visitors from the beginning of 2018 until the midyear, had a serious increase in September but the number of visitors continuously decreased from October to the end of the year.

How popular is milliyet.com.tr?

Alexa Traffic Ranks

How is this site ranked relative to other sites?

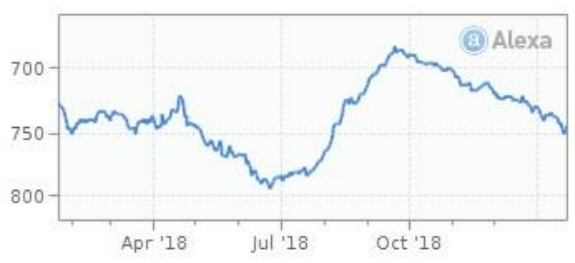

Global Rank 3

$7 4 4 \longdiv { - 4 5 }$

Rank in Turkey 2

四 17

Image 3: The general and country ranking of milliyet.com.tr according to the data of Alexa.

As it can be seen in Image 3, www.milliyet.com.tr had a zigzagging graphic in terms of visitors in 2018 . The site ranked $744^{\text {th }}$ in the world and $17^{\text {th }}$ in Turkey in the most visited sites ranking. According to the graphic, while the site had steady visitors at the first quarter of the year, the number of visitors decreased in July, increased until the last quarter of 2018 and decreased again towards the end of the year. 
How popular is yenisafak.com?

Alexa Traffic Ranks $\odot$

How is this site ranked relative to other sites?

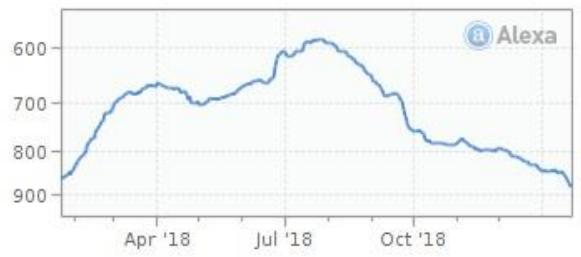

Image 4: The general and country ranking of yenisafak.com according to the data of Alexa.

As it can be seen in Image 4, www.yenisafak.com ranked $879^{\text {th }}$ in the world and $19^{\text {th }}$ in Turkey in the most visited sites ranking. According to the graphic, the site was visited a lot in midyear, on the contrary to the other news sites, but experienced decreases at the early and late months of the year.

\section{How popular is mynet.com?}

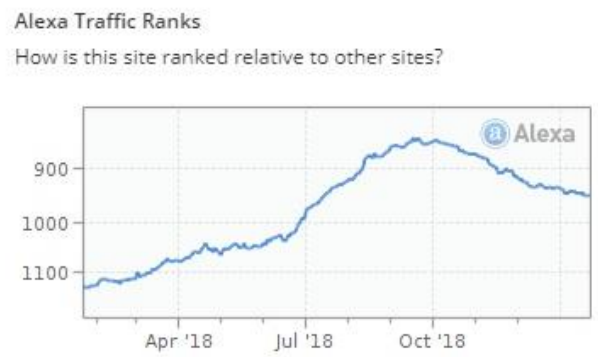

Image 5: The general and country ranking of mynet.com according to the data of Alexa. 
As it can be seen in Image 4, www.mynet.com ranked $948^{\text {th }}$ in the world and $20^{\text {th }}$ in Turkey in the most visited sites ranking. According to the graphic, the site experienced a substantial increase from the first month of 2018 until the last quarter of the year, peaked in September and demonstrated a decrease towards the end of the year.

\subsection{Examinations of Sample News}

\section{Sample 1:}

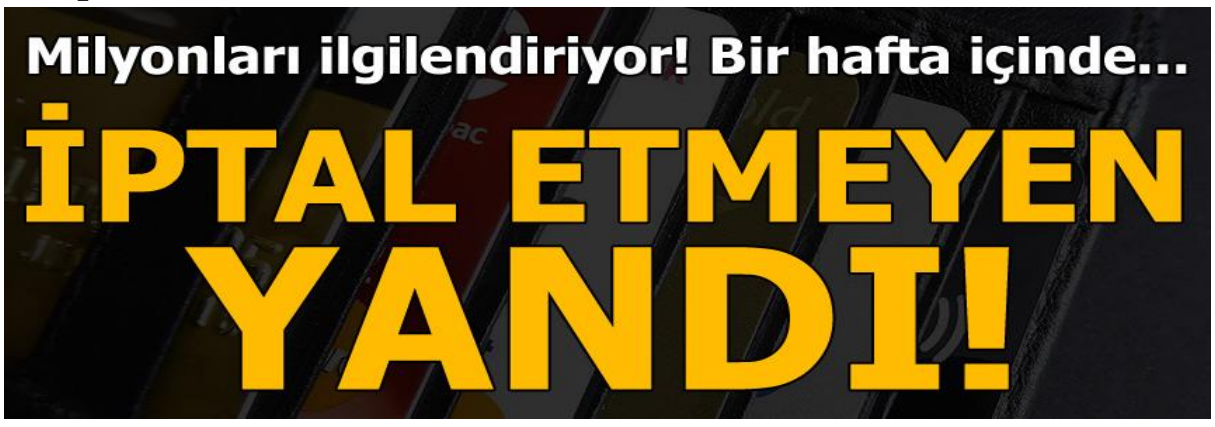

A news report in milliyet.com.tr on the date of January 16, 2019 was given with the title, "This concerns millions! Those who won't cancel... in a week are in big trouble!' The statement, "This concerns millions!" in the headline seems to indicate that the news report may concern every visitor in the site and the statement "those who won't cancel are in big trouble" indicate that missing this incident-report would cost to the visitor. There wasn't any information about the content of the incident in the news title. The report gave a message of "you are in big trouble", as if threatening the reader. But when the report was read it was seen that there will have been an enforcement for the banks which won't cancel credit cards, rather than an incident that concerned citizens. Thus, the title of the report was completely false and intended to deceive the reader.

When we clicked the link in the site, the news report was as follows;

"Newsflash: This concerns millions! The banks which won't cancel credit cards...

The banks which raise difficulties in card cancellation, during the restructuring of credit card debts will be followed. A legal action will be taken against the banks which won't cancel the cards. 
Restructuring of credit card debts with low interest rates which was initiated with Ziraat Bank and followed by Vakufbank, heated up the finance markets. Banking Regulation and Supervision Agency (BRSA) started to closely monitor banks which raise difficulty for the cancellation of the card. A legal action will be taken against the banks which raise difficulties and won't cancel the cards within a week after the consumer applies for the cancellation of the card. Income Adjustment to the Cards Cards that were given with high limits will be adjusted to the level of income. A person who carries a card with a limit of 50 thousand lira which exceeds one's income, will be able to get a card suitable for one's income when benefited from restructuring. The consumers will get another credit card if their limits are sufficient. A new credit card will be granted by Ziraat Bank if the consumers desire so, after the debt of the card is paid off. If the consumer does not desire, a new card won't be granted. While the restructured card will be invalid, the consumers will be able to use their other cards. The monthly installment which will be paid along with the consumer's other debts will be as $75 \%$ of the consumer's income.

Does This Involve Future Installments?

The restructuring of credit card debts does not involve future installments that are not in the credit card receipt. Only the installments that reflect on the receipt are restructured in installment shopping. For example, 10 thousand lira was withdrawn from the credit card as installment cash. It will only involve two installments if they are paid off in the receipt of November, December 2018. Credit support won't be provided for 8-month of installments that is not reflected on the receipt. People who are not in the files that were sent to asset management companies or are followed with legal proceedings won't be able to benefit from this opportunity." 


\section{Sample 2:}

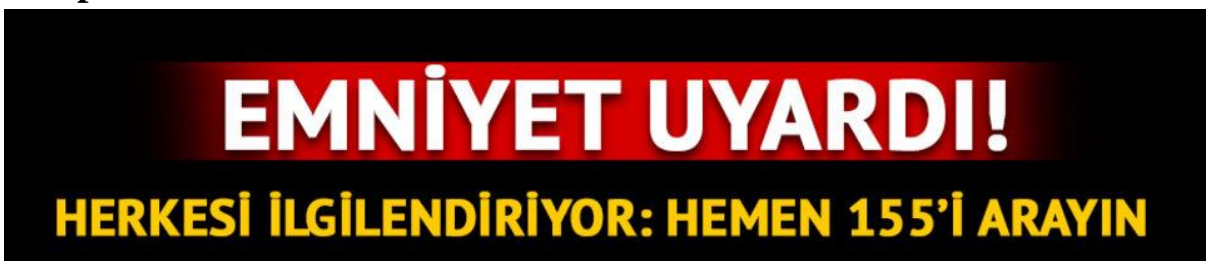

A news report in mynet.com on January 10, 2019 was given with the title, "The Police Warned! It Concerns Everybody: Call 155, immediately!" and it seemed to aim to raise discontent and anxiety. Furthermore, using a title as "It Concerns Everyone" caused/should have caused fear for everyone. In the title, the expression "The Police" was used instead of Provincial Directorate of Security in order to expand the influence area of the report. When the link to the report was clicked, it was understood that the statement was made by Giresun Provincial Directorate of Security. Thus, the report was in fact local. The site changed the wording of the report in order to make it an incident that concerns everybody and to make it to be clicked by more people.

When we clicked to the link in the site, the news report was as follows;

"Now it is 'Tanker Bank', after the Çiftlik Bank! The police warned.

Giresun Provincial Directorate of Security warned about an 'aggravated fraud' by making a statement on the official website. Giresun Provincial Directorate of Security warned about a fraud that is performed with a name called as 'Tanker Bank'.

"It Has Great Importance to Notify 155, Immediately"

The statement was, "Aggravated fraud which is performed with the promise of earning exorbitant sum of money by a pyramid scheme called as 'Tanker Bank' has appeared on printed and visual media. It is advised to our citizens to be careful against these organizations or people who promise wealth either on internet or social life so as not to incur material and non-material losses and to contact Police Emergency Line 155 immediately in the case of encountering an incident or victimization. Respectfully Announced to the Public."

Vanished into Thin Air with 70 Million Lira

After the 'Chiftlik Bank' incident which was created with a pyramid scheme, this time 'Tanker Bank' emerged. Mustafa Ç. who started 5 years ago and bought imaginary tanker and operated on behalf of shareholders, vanished into thin air 
with 70 million lira. Tanker Bank victim, H.E. stated that, "He collected money by saying, 'You just trust Allah first and then me"'.

\section{Sample 3:}

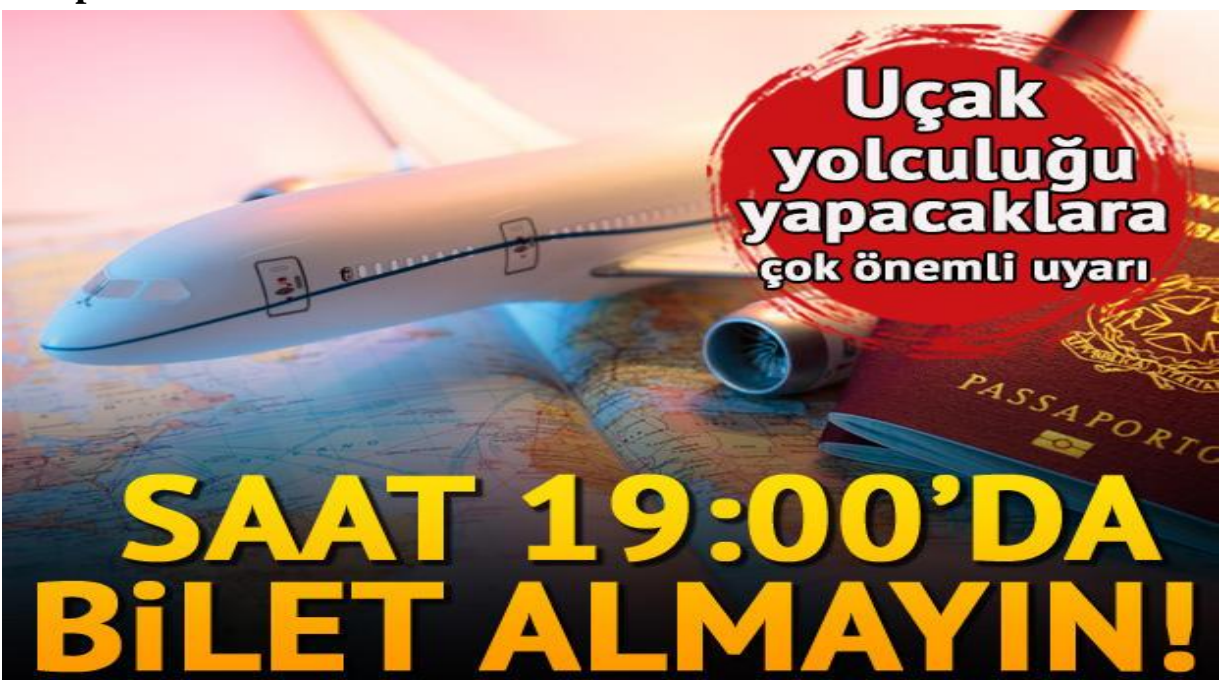

The title of a news report which was published on hurriyet.com.tr on January 16, 2019 was given as "A vital warning for those who will travel on airplane, Don't buy a ticket at 19:00!". The title of the news report which was thought to give important information about air travel of which many people are anxious about, was prepared in a style which would worry many readers. But when the link for the news report was clicked it was seen that the methods for buying cheap tickets were stated in the so-called news report with a gallery of 49 photographs. When the news report was clicked, there was a statement "Airplane ticket search engine Skyscanner gave striking clues for those who want to travel on airplane and will buy an airplane ticket. You must read it...", next to the first picture that the reader encountered. 
Sample 4:

\section{Milyonları ilgilendiriyor}
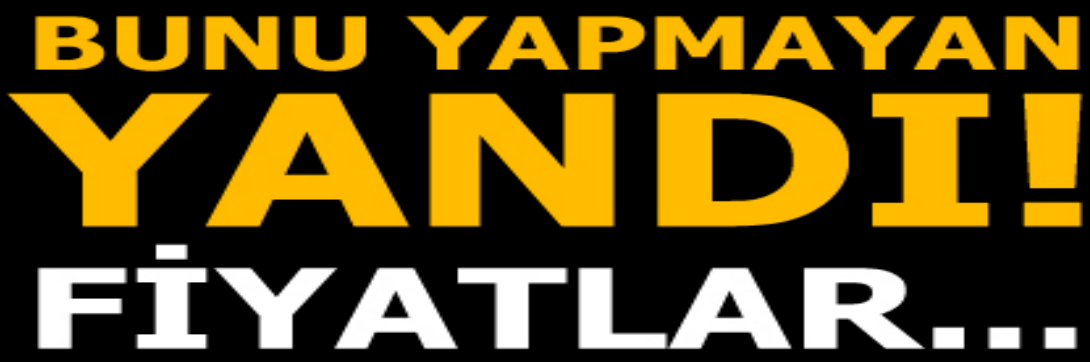

A news report which was given with the title "This concerns millions, Those who won't do this are in big trouble, The prices..." on milliyet.com.tr on January 30, 2019 seemed as if it was about a very important warning to the readers. As it can be understood from the title, those who wouldn't care for the warnings in the content of the news report are "in big trouble", according to the report. But when the link for the news report was clicked a statement was seen as, "Tomorrow is the last day for this year's first installment payment of Motor Vehicle Tax (MVT). Those who don't want to pay interest of default should pay their first MVT installment for their vehicle by the end of business day tomorrow.

\section{Sample 5:}

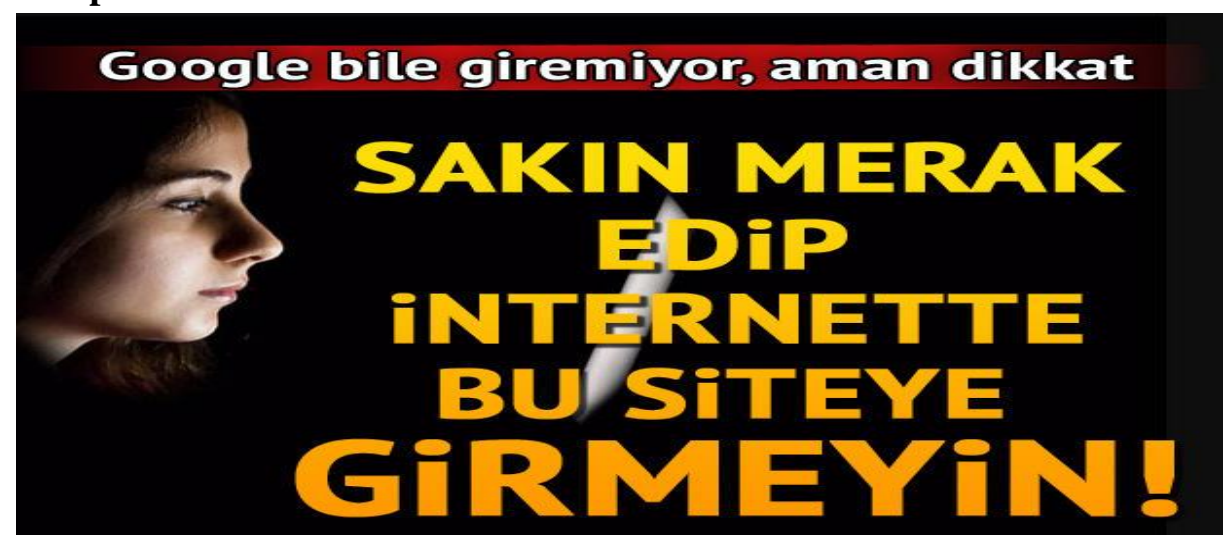


The title of a news report that was published on hurriyet.com.tr on January 08, 2019 seemed to aim all of the internet users. When the title with the warning "Even Google can't enter, Don't you ever enter this site out of curiosity" was clicked, the reader was directed to a gallery with 37 photographs of which the reader could not get an idea about the content. This report popped up to the readers who clicked the link in order to read it:

"Even Google can't access: Be careful against the Dark Web danger!

What is Deep Web which has no end? What is inside of Deep Web (Dark Web)? Why Deep Web is dangerous?

Even Google can't access: Be careful against the Dark Web danger!

We hear more from Deep Web lately. Because scary and secret things are tempting. More importantly, Deep Web includes $90 \%$ of the internet world, the $10 \%$ includes the websites that Google can access."

\subsection{The Statistics of News Reports Which Were Written with the Tones of Concerning, Frightening, Threatening etc.}

\begin{tabular}{|l|c|c|c|c|c|}
\hline \multicolumn{1}{|c|}{ News sites } & $\begin{array}{c}\text { The } \\
\text { number } \\
\text { of } \\
\text { examine } \\
\mathrm{d} \\
\text { headline } \\
\mathrm{s}\end{array}$ & $\begin{array}{c}\text { The } \\
\text { number of } \\
\text { concerning } \\
\text { frightening } \\
\text { threatenin } \\
\text { g etc. news }\end{array}$ & $\begin{array}{c}\text { The rate } \\
\text { of these } \\
\text { news on } \\
\text { headline } \\
\text { s (\%) }\end{array}$ & $\begin{array}{c}\text { The } \\
\text { numbe } \\
\text { r of } \\
\text { gallery } \\
\text { news }\end{array}$ & $\begin{array}{c}\text { The rate of } \\
\text { gallery in } \\
\text { concerning } \\
\text { frightening } \\
\text { threatenin } \\
\text { g etc. news } \\
(\%)\end{array}$ \\
\hline $\begin{array}{l}\text { Ensonhaber.co } \\
\text { m }\end{array}$ & $\mathbf{8 4 0}$ & - & - & - & - \\
\hline Milliyet.com.tr & $\mathbf{7 1 4}$ & 102 & $\mathbf{1 4 . 2 8 \%}$ & 27 & $26.46 \%$ \\
\hline Hurriyet.com.tr & $\mathbf{8 4 0}$ & 96 & $\mathbf{1 1 . 4 2 \%}$ & 46 & $47.9 \%$ \\
\hline Yenisafak.com & $\mathbf{7 1 4}$ & 8 & $\mathbf{1 . 1 2 \%}$ & - & - \\
\hline Mynet.com & $\mathbf{1 . 0 0 8}$ & 128 & $\mathbf{1 2 . 6 9 \%}$ & 6 & $4.68 \%$ \\
\hline
\end{tabular}


Table 1: The number of concerning, frightening, threatening etc. news and statistics of the most followed sites.

In Table 1, statistics of news sites that are followed the most in Turkey were given. As it can be understood from the table, except for ensonhaber.com and yenisafak.com, 3 news sites publish news report that threatens, frightens, concerns the reader and causes worry in the reader, which is also the subject of our study. As it can also be understood from the table, one of at least 10 news reports in these 3 news sites are in this tone. In other words, at least two of the headlines of these news sites are written in this tone.

When the statistics of news sites are evaluated, these 3 news sites present some of their news as gallery news, furthermore, hurriyet.com.tr publishes almost half of its news reports that are written in this tone as gallery news. The main reason for presenting the news as gallery news is to demonstrate high number of visitors by making the reader click more than once (as much as the number of gallery-photograph).

\section{Conclusion and Evaluation}

Fundamentally, journalism is an occupation which serves for public interest. It is expected from journalism to be sensitive while informing the society accurately, punctually and as easy-to-reach. Changes and transformations provided by the new technologies became prominent in journalism as they also had in many fields and caused journalism to migrate to the internet environment. However, this situation caused a differentiation in journalism especially in its writing and presentation. Internet news sites have tried and are trying completely different methods of news writing and presentations in order to hold on in this new environment, to increase the number of readers and to gain profit commercially. Unfortunately, this new type of journalism does not comply with any rule or principal. This study was conducted in order to reveal the creation of a new journalism understanding in internet journalism which has started to be used more recently and frightens, threatens the reader and causes concern in the reader by arousing curiosity.

When the study is examined generally, it can be understood that 3 out of 5 news sites that are followed the most in Turkey according to the data of Alexa publish 
news that tricks, deceives and frightens readers instead of informing them. It can be observed that these news sites include at least one news report that is written in this tone almost every day in their headlines and when it is evaluated proportionately, one of 6-7 news report is created in this way.

Within the scope of the research a total of 4119 news reports, 840 news reports from ensonhaber.com, 714 news reports from milliyet.com.tr, 840 from hurriyet.com.tr, 714 from yenisafak.com and 1008 from mynet.com, were examined for 2 months in the most followed 5 internet news sites and it was determined that 344 of these news reports were written in a style which frighten, concern and cause anxiety in the reader instead of arousing curiosity, which is the subject of this study. In the examination it was observed that the most followed news site in Turkey, ensonhaber.com, has never published a title/news report in this style and yenisafak.com has only published 8 news reports in this style. The most interesting and maybe the most important result from these data is that, although ensonhaber.com does not publish news in this style, it is the most followed website in Turkey. This situation shows us that it is possible to become a news site that readers prefer without making news in this style (frightening, concerning, threatening etc.).

Within the scope of the study, the content of websites on weekends were not taken into consideration since they are updated less. During the 42 days of process when the news examination was conducted, it was observed that milliyet.com included this type of news the most in terms of proportion (14.28\%), and mynet.com included these news reports the most in terms of numbers (128 pieces). As it can be also understood from the research that, hurriyet.com.tr aimed readers to click these news reports more by presenting almost half of the news reports $(47.9 \%)$ that were written in this style by presenting them in gallery news style.

As it can be understood from the sample news that the news reports which were written and presented in this style were created with an understanding which is exaggerated, noncompliant in terms of title and content, tires the reader and even makes it difficult to read. While these news reports disappoint the reader, 
they also cause journalism to be corrupted and deviated from its purpose. It is considered that this and these kind of studies carry great importance in terms of creating an occupational awareness. 


\section{REFERENCES}

Almagor, R. C. (2002). Ifade, Medya ve Etik ( $1^{\text {st }}$ Edition). (S.N. Şad, Trans.). Ankara: Phoenix Yayınevi

Arasl1, O. (2011). Internet ve internet haberciliği: Türkiye'deki popüler haber sitelerinin etiksel açıdan incelenmesi. (Master Thesis) Selçuk Üniversitesi Sosyal Bilimler Enstitüsü. Konya.

Aydın, İ. E. (2016). Üniversite Öğrencilerinin Sosyal Medya Kullanımları Üzerine Bir Araştırma: Anadolu Üniversitesi Örneği, Selçuk Üniversitesi Sosyal Bilimler Enstitüsü Dergisi, (35): 373-386.

Boyd, D. M. and Ellison, N. B., (2007). Social Network Sites: Definition, History, and Scholarship, Journal of Computer-Metiated Communication, Vol.13, No.1.

Bulunmaz, B. (2015). Yeni medya eski medyaya karş1: savaşı kim kazandı ya da kim kazanacak? Karadeniz Teknik Üniversitesi İletişim Araştırmaları $\begin{array}{lllll}\text { Dergisi, } & 1 & \text { (7), } & \text { 22-29. } & \text { Retrieved }\end{array}$ http://dergipark.gov.tr/ktuiad/issue/10316/126540

Cereci, S. Ve Özdemir H. (2015). Medyanın Toplumsal Gelişimi: Medya Toplumları, The Journal of Academic Social Science Studies, Number: 33, p. 110, Spring I 2015

Çakır, H. ve Topçu, H. (2005). Bir iletişim dili olarak İnternet. Erciyes Üniversitesi Sosyal Bilimler Enstitüsü Dergisi, 19 (2), 71-96.

Çalışır, G. (2015). Kişilerarası İletişimde Kullanılan Bir Araç Olarak Sosyal Medya: Gümüşhane Üniversitesi İletişim Fakültesi Öğrencilerine Yönelik Bir Çalışma, NWSA-Humanities E-Journal of New World Sciences Academy, 10 (3), 115-144.

Demir, V. (2006). Medya etiği (1 ${ }^{\text {st }}$ Edition). İstanbul, Beta Basım.

Dönmez, İ. H. (2010). İnternet haberciliğinde tıklanma kaygısı ve kapan manşetler. Akdeniz Üniversitesi İletişim Fakültesi Dergisi, 14, 105-128. 
Englander, F., Terregrossa, R. A., Wang, Z. (2010). Internet Use Among College Student: too or toy? Educational Review, 62(1), 85-96.

Erdoğan, İ. (2013). Yeni medya gazeteciliğinde etik bir paradigma belirlemenin kapsamı ve sinırları. Iletişim Kuram ve Araştırma Dergisi, Sayı:36, Bahar, Gazi Üniversitesi İletişim Fakültesi, Süreli Elektronik Dergi, ss.254-272.

Fouts, J. (2009). Social Media Success: Practical Advice and Real-World Examples for Social, California: Happyabout İnfo.

Furedi, F. (2001) Korku Kültürü, (B. Y1ldırım, Trans.) İstanbul: Ayrınt1 Yayınları

Gençlik ve Spor Bakanlığı, (2017) Dünya ülkeleri internet ve sosyal medya kullanımı, Gençlik Araştırmaları Haber Bülteni, Sayı 2, 2017

Gürcan, H. İ. (2005). İnternet haberciliğinde etik değerler, İstanbul Üniversitesi Illetişim Fakültesi Dergisi, Sayı 22, 39-46

Hazar, M. (2011). Sosyal Medya Bağımlılığı- Bir Alan Çalışması, Gazi Üniversitesi İletişim Fakültesi İletişim Kuram ve Araştırma Dergisi, Sayı 32.

Iş1k, U. ve Koz, K. A. (2014). Çöp yığınlarında haber aramak: internet gazeteciliği üzerine bir çalışma. Humanities Science, 9 (2), 27-43.

İnce, M. (2018). Haber edinme aract olarak internet ve internet haberciliği, Konya: Eğitim Yayınevi

İnce, M. ve Koçak, M. C. (2017). Üniversite Öğrencilerinin Sosyal Medya Kullanım Alışkanlıkları: Necmettin Erbakan Üniversitesi Örneği, Karabük Üniversitesi Sosyal Bilimler Enstitüsü Dergisi, Cilt: 7, Sayı: 2, ss.736-749

Kalsın, B. (2016). Geçmişten Geleceğe İnternet Gazeteciliği: Türkiye Örneği, The Journal of Academic Social Science Studies, Number: 42, p. 75-94, Winter III 2016, (ss.75-94),

Karppinen, K. and Moe, H. (2014). What we talk about when we talk about "The Market": Conceptual contestation in contemporary media policy research, Journal of Information Policy, (4), 327-341. 
Kirtiş, K. A., Karahan, F. (2011). To be or not to be in Social Media Arena as the Most Cost-efficient Marketing Strategy after the Global Recession. Procedia Social and Behavioral Sciences, 24, 260-268.

Köknel, Ö. (2004). Korkular, Takıntılar, Saplantılar. İstanbul: Altın Kitaplar. Küçükali, A. (2016). Üniversite Öğrencilerinin Sosyal Medya Kullanımı: Atatürk Üniversitesi Örneği, Bartın Üniversitesi İI.I.B.F. Dergisi, 7, (13)

Lee, A. M., Lewis, S. C. ve Powers, M. (2014). Audience clicks and news placement: a study of time-lagged influence in online journalism.

Communication Research 41 (4), 505-530. doi:10.1177/0093650212467031.

Lüsted, A. M. (2011). Social Networking: Myspace, Facebook and Twitter, America: ABDO Publishing Company.

Obee, J. (2012). The Ultimate Teen Guide, Toronto: The Scarecrow Press.

Onat, F., Alikılıç, Ö. A. (2008). Sosyal ağ sitelerinin reklam ve halkla ilişkiler ortamları olarak değerlendirilmesi, Journal of Yaşar University, 3(9), 11111143.

Öner, T. (2006). Bilişimde Özenli Türkçenin Önemi, Bilişim ve Bilgisayar Mühendisliği Dergisi, 1 (1), İstanbul.

Özdemir, S. S., ve Diğerleri (2014) Sosyal medya kavramı ve sosyal ağ sitelerinde yer alan online reklam uygulamalarının incelenmesi, Electronic Journal of Vocational Colleges-December 2014

Özyal, B. (2016). T1k odaklı habercilik: tık odaklı haberciliğin Türk dijital gazetelerindeki kullanım biçimleri. Global Media Journal TR Edition, 6, 12, 273-301.

Pavlik, J.V. (2013). Yeni Medya ve Gazetecilik. (M. Demir ve B. Kalsın, Trans.) Ankara: Phoe

Ryan, K. P. (2011). Social Networking, New York: Rosen Publishing.

Tektaş, N. (2014). Üniversite Öğrencilerinin Sosyal Ağları Kullanımlarına Yönelik Bir Araştırma, Journal of History School (JOHS), 7(17): 851-870. 
Torun, H. (2018). Görsel Korkuda Yönelim ve Popüler Kültür. Yıldız Journal of Art and Design, 5 (1), 63-84.

Tosun, C. (2005). Dil Zenginliği, Yozlaşma ve Türkçe. Journal of Language and Linguistic Studies, 1 (2), 136-153.

Van Dijck, J. (2013). The Culture of Connectivity: A Critical History of Social Media, Oxford: Oxford University Press.

Yurdigil, Y. ve Zinderen, İ.E. (2012). Yeni Medyada Haber Dili (Ayşe Paşalı Olayı Üzerinden Geleneksel Medya Ve İnternet Haberciliği Karşılaştırması), The Turkish Online Journal of Design, Art and Communication- TOJDAC July 2012, Volume 2 Issue 3, (ss. 81-91)

\section{Online Resources}

www.milliyet.com.tr

www.mynet.com

www.hurriyet.com.tr

www.ensonhaber.com

www.yenisafak.com

http://www.milliyet.com.tr/karti-iptal-etmeyen-banka-ekonomi-2812178/

https://www.mynet.com/ciftlik-bank-tan-sonra-simdi-de-tanker-bank-emniyetuyardi-190101134779

http://www.hurriyet.com.tr/galeri-skyscanner-saat-19-00da-kesinlikle-ucakbileti-satin-almayin-41083659

http://www.milliyet.com.tr/iste-2019-un-vergi-takvimi-ekonomi-galeri$2819487 /$

http://www.hurriyet.com.tr/galeri-google-bile-erisemiyor-dark-webtehlikesine-aman-dikkat-41076318 